\title{
Małe i średnie przedsiębiorstwa w systemie zamówień publicznych polski na tle unii europejskiej
}

\author{
Wiktor Płóciennik \\ Doktorant Uniwersytetu Łódzkiego \\ http://dx.doi.org/10.18778/8088-114-3.12
}

Sektor małych i średnich przedsiębiorstw (MSP) traktowany jest powszechnie jako ten element gospodarki, który w sposób szczególnie efektywny ją dynamizuje. Systemowe ułatwienia dostępu sektora MSP do rynku zamówień publicznych są zatem jednym z kluczowych celów polityki zamówień publicznych, zarówno w Unii Europejskiej, jak i w Polsce. Cel ten, jako szczególnie istotny, znajduje zatem swoje odzwierciedlenie zarówno w aktualnie obowiązujących, jak i przewidywanych do wprowadzenia aktach normatywnych ${ }^{1}$ oraz $\mathrm{w}$ poważnych opracowaniach o charakterze studialnym.

W tej sytuacji celem niniejszego referatu jest dokonanie charakterystyki zarówno krajowych, jak i unijnych rozwiązań mających ułatwić małym i średnim przedsiębiorstwom dostęp do kontraktów publicznych.

1 Mamy tu na myśli w szczególności dyrektywę 2004/18/WE z 31.03.2004 r. w sprawie koordynacji procedur udzielania zamówień publicznych na roboty budowlane, dostawy i usługi (Dz.U. L134 z 30.04.2004 r., s. 114 oraz dyrektywę 2014/24/UE z 26.02.2014 r. w sprawie zamówień publicznych uchylającą dyrektywę 2004/18/WE (Dz.U. L94 z 28.03.2014 r., s. 65 jak również ustawę z 29.01.2004 r. - Prawo zamówień publicznych (Dz.U. z 2013 r., poz. 907, ze zm.) oraz ustawę Prawo zamówień publicznych (projekt z dnia 17.04.2015 r. dostępny na stronie www.uzp.gov.pl.). 


\section{Ułatwienia w dostępie MSP do rynków zamówień publicznych UE}

\subsection{Rozwiązania proponowane w dokumentach UE}

„Regulacje prawne Unii jak i jej działania mają na celu otwarcie rynku zamówień publicznych poprzez zwiększenie udziału MSP jako potencjalnych wykonawców². Oczywiste jest, że MSP stanowią podstawę gospodarki państw członkowskich i Unii. Za ważny z punktu widzenia zamówień publicznych uznaje się ogromny potencjał tej grupy przedsiębiorców w zakresie tworzenia miejsc pracy, wzrostu gospodarczego i innowacji. (...) Należy zatem podejmować działania, głównie prawne, które będą ułatwiały dostęp i otwierały ten rynek na MSP3". Naturalną konsekwencją tej tezy było pojawienie się problematyki dostępności sektora MSP do rynku zamówień publicznych w licznych oficjalnych dokumentach organów wykonawczych Unii Europejskiej.

Pierwszym z nich była wydana już w 1998 roku Zielona Księga ${ }^{4}$. Jednym $\mathrm{z}$ poruszanych $\mathrm{w}$ tym dokumencie aspektów był sposób, w jaki można połączyć politykę zamówień publicznych z pozostałymi kierunkami działań wytyczonymi przez Wspólnotę, a w szczególności dotyczącymi małych i średnich przedsiębiorstw, normalizacji, sieci transeuropejskich (TEN), Funduszy Strukturalnego i Spójności, zamówień udzielanych przez europejskie instytucje lub finansowanych z funduszy Wspólnoty w dziedzinie polityki społecznej, środowiska naturalnego i sektora obrony narodowej. Dokument przedstawiał listę przeszkód na jakie napotykały małe i średnie przedsiębiorstwa $\mathrm{w}$ procedurze pozyskiwania kontraktów publicznych oraz zawierał propozycje działań zmierzających do poprawy sytuacji MSP na rynku zamówień publicznych. Wspomniana lista eksponowała takie utrudnienia jak:

- trudności związane z dostępem do informacji niezbędnych do przygotowania oferty,

- zbyt wysokie dla MSP koszty przygotowania i składania ofert oraz

- konieczność zapewnienia wymaganych gwarancji finansowych według konkurencyjnych stawek.

2 Zagadnienie dostępności rynku zamówień publicznych było również tematem konferencji organizowanych przez instytucje UE, np. „On the Modernization of European Public Procurement Policy: Towards a more Efficient European Procurement Market", Bruksela, 1 lipca 2011 r.

3 System zamówień publicznych w Polsce, red. J. Sadowy, Warszawa 2013, s. 38.

4 Zielona Księga. Zamówienia publiczne w Unii Europejskiej - w poszukiwaniu rozwiq̨zań, Komisja Europejska, Bruksela 1998 r. 
Postulowane ułatwienia MSP dostępu do zamówień publicznych obejmowały natomiast:

- zagwarantowanie terminowych płatności za roboty, dostawy lub usługi zrealizowane przez MSP;

- postulat rozstrzygania wszelkich sporów w sposób szybki i tani oraz

- postulat otrzymania odpowiedniego zabezpieczenia przez MSP występujące w roli podwykonawców zamówień publicznych.

Omawiany dokument posłużył za podstawę do opracowania zmian legislacyjnych dotyczących systemu zamówień publicznych.

W 2008 roku Komisja Europejska opublikowała Europejski kodeks najlepszych praktyk ułatwiających dostęp MSP do zamówień publicznych. W kodeksie tym po raz kolejny wskazano na bardzo istotną rolę MSP na rynku zamówień publicznych oraz uszczegółowiono szereg praktyk mieszczących się $\mathrm{w}$ ramach już istniejących rozwiązań prawnych UE, które $\mathrm{w}$ założeniu miały zapewnić optymalną organizację postępowań, jeśli chodzi o udział MSP i zapewnienie im równych szans w konfrontacji z przedsiębiorstwami dużymi ${ }^{5}$.

Inicjatywę w sprawie dostępu sektora MSP do rynku zamówień publicznych podjął również Parlament Europejski. W 2009 roku skierował on do Komisji Europejskiej wniosek o podjęcie większych wysiłków na rzecz ułatwienia dostępu MSP do rynków zamówieniowych. Postulat ten zawarty został $\mathrm{w}$ sprawozdaniu poświęconym rozwojowi sytuacji $\mathrm{w}$ dziedzinie zamówień publicznych ${ }^{6}$.

W 2010 roku zaprezentowana została Strategia na rzecz wzrostu gospodarczego i zatrudnienia Europa 2020. Zapisano w niej m.in., iż „zamówienia publiczne, stanowiąc jedno $\mathrm{z}$ narzędzi rynkowych, które powinny służyć do realizacji powyższych celów, są kluczowym elementem strategii »Europa 2020«. W szczególności w strategii »Europa 2020« postuluje się, aby poprzez zamówienia publiczne: (...) poprawić otoczenie biznesu, szczególnie w odniesieniu do MSP?”.

Kolejnym istotnym dokumentem, powstałym jako następstwo wdrażania strategii Europa 2020 jest Zielona Ksiega w sprawie modernizacji polityki UE w dziedzinie zamówień publicznych ${ }^{8}$. Zielona Księga podnosiła

5 Europejski kodeks najlepszych praktyk ułatwiających dostęp MSI do zamówień publicznych, Komisja Wspólnot Europejskich, Dokument roboczy Służb Komisji, Bruksela 2008.

6 New developments in public procurement: 2009/2175(INI)), Parlament Europejski Bruksela, Strasbourg 2009.

7 Komunikat Komisji Europejskiej z 3.03.2010 roku, Europa 2020, Strategia na rzecz inteligentnego i zrównoważonego rozwoju sprzyjającego włączeniu społecznemu.

8 Zielona Księga w sprawie modernizacji polityki UE w dziedzinie zamówień publicznych. W kierunku zwiększenia skuteczności europejskiego rynku zamówień, Komisja Europejska, Bruksela, 27 styczeń 2011. 
również tematykę dostępu małych i średnich przedsiębiorstw do rynku zamówień publicznych. Zdaniem jej autorów, sektor MSP stanowi podstawę gospodarki UE, natomiast ułatwienie małym i średnim przedsiębiorstwom dostępu do rynku zamówień publicznych powinno wywrzeć korzystny wpływ na gospodarkę krajów członkowskich oraz, zwiększając liczbę potencjalnych wykonawców tych zamówień, pozytywnie wpłynąć na poziom konkurencyjności realizowanych postępowań.

Zielona Księga analizuje potencjalne kierunki działań ustawodawczych koniecznych do pełnego wykorzystania ekonomicznego i innowacyjnego potencjału sektora małych i średnich przedsiębiorstw przez instytucje zamawiające w ramach ich transakcji zamówieniowych. Dokument nie odnosił się wprost do Zielonej Księgi z 1998 roku, jednakże jako dwie główne przyczyny niezadowalającego dostępu MSP do rynku zamówień publicznych wskazywał:

- nadmierne obciążenia administracyjne wykonawców na etapie kwalifikacji podmiotowej oraz

- nadmiernie wyśrubowane kryteria tej kwalifikacji.

Powyższe elementy, opisane $\mathrm{w}$ nieco szerszym zakresie, pojawiły się już w poprzedniej Zielonej Księdze, co świadczy o tym, iż nie wszystkie działania korygujące wdrożone w okresie 1998-2011 przyniosły pożądane efekty. Autorzy wskazują postulowane, kierunkowe metody interwencji ustawodawcy, mające neutralizować stwierdzone przez nich przyczyny niezadowalającego stanu rzeczy w ramach nowego prawa regulującego system zamówień publicznych?

Jako pierwszą z tych metod autorzy wymieniają dopuszczenie możliwości przedstawiania przez przedsiębiorstwa $\mathrm{w}$ początkowej fazie postępowania o udzielenie zamówienia jedynie streszczenia informacji istotnych do celów kwalifikacji podmiotowej oraz dostarczanie oświadczeń własnych dotyczących spełniania warunków podmiotowych. Co do zasady, jedynie zwycięski oferent lub oferenci dopuszczeni do etapu udzielenia zamówienia zostaliby poproszeni o przedstawienie pierwotnych dokumentów (zaświadczeń) potwierdzających spełnianie warunków udziału w postępowaniu.

Drugą postulowaną metodą było wprowadzenie ograniczenia w zakresie określania maksymalnych poziomów niektórych wymogów dotyczących kwalifikacji podmiotowej, odnoszących się w szczególności do sytuacji finansowej. Mogłoby to zapobiec określaniu przez instytucje zamawiające nadmiernie wyśrubowanych kryteriów kwalifikacji wykonawców, które w sposób nieuchronny wykluczają z udziału MSP. Tego rodzaju środek stanowiłby jedynie rozwinięcie istniejącego już obowiązku stosowania przy określaniu kryteriów kwalifikacji wykonawców zasady proporcjonalności.

9 Ibidem, s. 31-33. 
Trzecią metodą ułatwiającą MSP dostęp do zamówień publicznych mogłoby być wprowadzenie środków pozytywnej dyskryminacji na rzecz MSP, takich jak na przykład zastrzeganie z góry części zamówień wyłącznie dla tej grupy przedsiębiorstw. Tego rodzaju działania byłyby jednakże sprzeczne z zasadą równego traktowania oferentów, która stanowi istotny filar systemu UE dotyczącego zamówień publicznych i która została potwierdzona przez Trybunał Sprawiedliwości jako jedna ze swobód wynikających z Traktatu. W tej sytuacji autorzy Zielonej Księgi postulują wprowadzenie wewnętrznych środków administracyjnych zachęcających instytucje zamawiające do dołożenia wszelkich starań w celu poprawy dostępu MSP do udzielanych przez nie zamówień. Jednym z nich może być np. ustalenie wartości docelowych dotyczących udziału MSP w całości udzielanych zamówień. Tego rodzaju rozwiązanie nie polegałoby na zastrzeganiu określonych zamówień dla MSP, lecz dostarczałoby po prostu instytucjom zamawiającym zachęt do jak najlepszego wykorzystania dostępnych instrumentów na rzecz prowadzenia przyjaznej dla MSP polityki zamówieniowej.

Czwartą metodą rozważaną $\mathrm{w}$ omawianym dokumencie UE jest nakładanie na zwycięskiego oferenta obowiązku zlecania osobom trzecim realizacji części zamówienia o określonej procentowo wartości. Innym sposobem zastosowania $\mathrm{w}$ praktyce omawianej metody promowania MSP mogłoby być wprowadzenie, jako zasady, postulatu dzielenia zamówienia publicznego na części. Postulat ten zrealizowano w nowej dyrektywie klasycznej (patrz punkt 1.2.).

\subsection{Rozwiązania wynikające z dyrektyw UE}

Jedną z najbardziej widocznych dysfunkcjonalności systemu zamówień publicznych w UE jest niezadowalająca absorpcja przez małe i średnie przedsiębiorstwa kontraktów z rynku zamówień publicznych, a w szczególności kontraktów o wartościach powyżej tzw. progów UE. Konieczność zmiany tej sytuacji była jednym z powodów opracowania nowych dyrektyw regulujących sposób udzielania zamówień publicznych. Nowa dyrektywa klasyczna tj. Dyrektywa Parlamentu Europejskiego i Rady 2014/24/UE z dnia 26 lutego 2014 r. w sprawie zamówień publicznych, uchylająca dyrektywę, 2004/18/WE wprowadza wiele ułatwień dla podmiotów sektora MSP. Implementacja tych nowych przepisów do polskiego systemu prawnego powinna w perspektywie najbliższych lat doprowadzić do zwiększenia udziału małych i średnich przedsiębiorstw w rynku zamówień publicznych w naszym kraju.

Dla bardziej pogłębionego i precyzyjnego ukazania intencji prawodawcy unijnego w odniesieniu do omawianego problemu przedstawimy 
w niniejszym punkcie referatu charakterystykę ułatwień dedykowanych sektorowi MSP w najnowszej dyrektywie klasycznej UE. Punktem odniesienia dla tej prezentacji będą analogiczne rozwiązania, jakie wynikały $\mathrm{z}$ dyrektywy poprzednio obowiązującej ${ }^{10}$.

Ograniczenie się w tym przeglądzie wyłącznie do dyrektyw klasycznych znajduje uzasadnienie $\mathrm{w}$ fakcie, iż są one w prawie unijnym podstawowym źródłem systemowych ułatwień dla sektora MSP.

Pierwszą zmianą korzystną dla sektora MSP jest zmiana definicji wykonawcy zapisana w art. 2 ust. 1 pkt 10 dyrektywy 2014/24/WE. $\mathrm{Na}$ podkreślenie zasługuje fakt dowartościowania w przywołanej definicji grupy osób lub podmiotów ${ }^{11}$ jako wykonawców zamówień publicznych. Dowartościowanie to polega na dodaniu zwrotu z którego wynika, iż pojęcie "grupy osób lub podmiotów" użyte w omawianej definicji odnosić się może również do „tymczasowych stowarzyszeń przedsiębiorstw, które oferują na rynku wykonanie robót budowlanych lub obiektu budowlanego, dostaw lub usług". Omawiane rozwiązanie w sposób oczywisty wychodzi naprzeciw oczekiwaniom MSP. Dla małych i średnich przedsiębiorstw możliwość utworzenia „grupy osób lub podmiotów" może stworzyć bowiem jedyną okazję, aby w konkurencji z przedsiębiorstwami dużymi, z szansą na sukces ubiegać się o zamówienie publiczne.

Funkcjonalne uzupełnienie definicji wykonawcy stanowi art. 19 ust. 2 nowej dyrektywy. Wynika z niego, że zamawiający nie mogą od tymczasowego stowarzyszenia wykonawców żądać posiadania określonej formy prawnej. Powyższa regulacja daje szerokie możliwości tworzenia przez małych i średnich przedsiębiorców ad hoc i bez nadmiernej formalizacji grupy podmiotów, która będzie ubiegała się o zamówienie publiczne. Rozwiązanie analogiczne zapisane było również w art. 4 ust. 2 dyrektywy klasycznej obowiązującej poprzednio. W nowej dyrektywie prawodawca unijny poszedł jednak o krok dalej uzupełniając art. 19 ust. 2 regulacją treści następującej: „W razie potrzeby instytucje zamawiające mogą w dokumentach zamówienia sprecyzować sposób, w jaki grupy wykonawców mają spełniać wymogi dotyczące sytuacji ekonomicznej i finansowej lub zdolności technicznej i zawodowej, o których mowa w art. 58, pod warunkiem, że jest to obiektywnie uzasadnione i proporcjonalne ${ }^{12}$. Państwa członkowskie mogą określić standardowe warunki określające, w jaki sposób grupy wykonawców mają spełniać te wymogi.

10 Mowa tu o dyrektywie 2004/18/WE.

11 Pojęcie „grupy osób lub podmiotów” jako wykonawcy zamówienia publicznego zastosowane było również w dyrektywie 2004/18/WE.

12 Artykuł 58 dyrektywy 2014/24/WE zatytułowany „Kryteria Kwalifikacji” normuje problematykę warunków udziału w postępowaniu. 
Warunki realizacji zamówienia przez takie grupy wykonawców odmienne od warunków nakładanych na pojedynczych uczestników muszą również być „obiektywnie uzasadnione i proporcjonalne”.

Z przywołanego przepisu dyrektywy wynika, iż:

- zamawiający ma prawo określić sposób oceny spełnienia warunków udziału w postępowaniu odmiennie dla grup wykonawców oraz dla wykonawców pojedynczych,

- państwa członkowskie mogą (fakultatywnie) w prawie krajowym unormować problem oceny podmiotowej grup wykonawców,

- warunki dedykowane grupom wykonawców muszą być obiektywnie uzasadnione i proporcjonalne - podobnie jak to ma miejsce w odniesieniu do wykonawców pojedynczych.

Problematykę badania podmiotowego w nowej dyrektywie klasycznej, w sposób korzystny dla sektora MSP, uzupełnia przepis art. 58 ust. 3. Stanowi on między innymi, że „minimalny roczny obrót, który muszą wykonać wykonawcy, nie przekracza maksymalnie dwukrotności szacunkowej wartości zamówienia”. W przypadku zamówienia podzielonego na części przywołany przepis nakazuje stosowanie wprowadzonej przezeń zasady w odniesieniu do każdej z nich.

Należy podkreślić, iż tego rodzaju rozwiązanie limitujące górny pułap wymagań wobec możliwości finansowych wykonawców, nie miało swojego odpowiednika w poprzednio obowiązującej dyrektywie klasycznej.

Do grupy postanowień nowej dyrektywy klasycznej które precyzują wymagania dotyczące badania podmiotowego w sposób potencjalnie korzystny dla MSP należy zaliczyć również przepis art. 18 ust. 1. Nakazuje on zamawiającym równe i niedyskryminacyjne traktowanie wszystkich wykonawców oraz działanie w sposób przejrzysty i proporcjonalny. Aczkolwiek podany nakaz zawierała również $\mathrm{w}$ art. 2 dyrektywa poprzednio obowiązująca, to jednak nowa dyrektywa klasyczna nakaz ten rozwija i precyzuje wprowadzając pojęcie: „sztucznego zawężania konkurencji”. Inkryminowane działanie polegać ma, zgodnie z omawianym przepisem, na zorganizowaniu procedury zamówienia „Z zamiarem nieuzasadnionego działania na korzyść lub niekorzyść niektórych wykonawców”, czyli na przykład na niekorzyść podmiotów należących do sektora MSP.

Problematykę badania podmiotowego w sposób korzystny dla MSP aczkolwiek nie zmieniony w stosunku do dyrektywy obowiązującej poprzednio, domyka art. 63. Jest to przepis stanowiący, iż w odniesieniu do kryteriów dotyczących sytuacji ekonomicznej i finansowej oraz kryteriów dotyczących zdolności technicznej i zawodowej, wykonawca lub grupa wykonawców może polegać na zdolnościach innych podmiotów, niezależnie od charakteru prawnego łącznych ich powiązań. W dyrektywie 2004/18/WE analogiczne uwarunkowania były treścią art. 47 ust. 2 i 3 oraz art. 48 ust. 3 i 4. 
Rozwiązaniem, które, potencjalnie rzecz biorąc, może być szczególnie istotnym ułatwieniem dla MSP w ich partycypacji w rynkach zamówień publicznych, jest nowe podejście prawodawcy unijnego do podziału zamówień publicznych na części. Dyrektywa 2014/24/WE mianowicie przyznaje państwom członkowskim prawo do „ustanowienia obowiązku udzielenia zamówień w formie oddzielnych części na warunkach określonych zgodnie ze swoim prawem krajowym i z uwzględnieniem prawa unijnego" (ust. 4). W przypadku zamówień, których obowiązek podziału na części nie będzie dotyczył, instytucje zamawiające zobowiązane zostały do „wskazania najważniejszych powodów swojej decyzji o niedokonaniu podziału na części” i umieszczenia tych powodów w dokumentach zamówienia wyszczególnionych w dyrektywie (ust. 1 akapit drugi).

Należy podkreślić, iż omówione rozwiązanie nie znajduje swojego odpowiednika w żadnej z dyrektyw obowiązujących poprzednio.

\subsection{Statystyczna prezentacja problemu}

Sektor małych i średnich przedsiębiorstw odgrywa na całym świecie kluczową rolę w kreowaniu wzrostu gospodarczego w większości branż współczesnej gospodarki. Znaczenie sektora MSP dla gospodarki europejskiej oraz, porównawczo, dla gospodarki polskiej przedstawia tabela 1.

\begin{tabular}{|r|l|r|r|r|r|r|r|}
\hline \multirow{2}{*}{ Lp. } & \multirow{2}{*}{$\begin{array}{c}\text { Rodzaj } \\
\text { przedsiębiorstwa }\end{array}$} & \multicolumn{6}{|c|}{ Udział MSP w gospodarce według: } \\
\cline { 3 - 8 } & & \multicolumn{2}{l|}{ liczby przedsiębiorstw } & liczby pracowników & \multicolumn{2}{c|}{ wartości dodanej } \\
\cline { 3 - 8 } & & UE & Polska & UE & Polska & UE & Polska \\
\hline 1 & Mikro & 92,4 & 95,2 & 29,1 & 36,5 & 21,6 & 14,7 \\
\hline 2 & Małe & 6,4 & 3,6 & 20,6 & 13,6 & 18,2 & 14,4 \\
\hline 3 & Średnie & 1,0 & 1,0 & 17,2 & 18,8 & 18,3 & 20,9 \\
\hline 4 & MSP ogółem & 99,8 & 99,8 & 66,9 & 68,9 & 58,1 & 50,0 \\
\hline 5 & Duże & 0,2 & 0,2 & 33,1 & 31,1 & 41,9 & 50,0 \\
\hline 6 & Razem & 100,0 & 100,0 & 100,0 & 100,0 & 100,0 & 100,0 \\
\hline
\end{tabular}

Tabela 1. Udział podmiotów sektora MSP w gospodarce UE oraz w gospodarce polskiej na przykładzie 2013 roku (w \%) Źródło: Przedsiębiorstwa i przemysł. Arkusz informacyjny SBA - 2014, Komisja Europejska, 2014 r.

Na podstawie danych zamieszczonych w tabeli 1 można stwierdzić, że znaczenie sektora MSP w gospodarce europejskiej faktycznie jest istotne, natomiast wskaźniki, które to znaczenie wyrażają w odniesieniu do gospodarki polskiej niewiele tylko swoim poziomem odbiegają od średnich europejskich i to jedynie w odniesieniu do udziału MSP w wytworzonej wartości dodanej. 
$\mathrm{Na}$ tle przedstawionych danych liczbowych udział sektora MSP w europejskim rynku zamówień publicznych jest znacznie niższy. Świadczy to o niedowartościowaniu sektora MSP na tym rynku. W latach 2006-2008 udział ten bowiem kształtował się w sposób pokazany w tabeli 2. Różnice pomiędzy wskaźnikami udziału w rynkach zamówień publicznych oraz w gospodarkach poszczególnych krajów UE ilustruje natomiast wykres 1.

\begin{tabular}{|c|l|c|c|c|c|c|}
\hline \multirow{2}{*}{ Lp. } & \multirow{2}{*}{ Kraj } & \multicolumn{5}{|c|}{ Wielkość przedsiębiorstw } \\
\cline { 2 - 7 } & & mikro & małe & średnie & MSP ogółem & duże \\
\hline 1 & Bułgaria & 16 & 33 & 30 & 79 & 21 \\
\hline 2 & Łotwa & 5 & 11 & 47 & 62 & 38 \\
\hline 3 & Malta & 7 & 25 & 29 & 62 & 38 \\
\hline 4 & Luksemburg & 12 & 13 & 28 & 53 & 47 \\
\hline 5 & Grecja & 15 & 4 & 33 & 52 & 48 \\
\hline 6 & Estonia & 7 & 16 & 25 & 49 & 51 \\
\hline 7 & Węgry & 8 & 21 & 19 & 47 & 53 \\
\hline 8 & Słowacja & 7 & 17 & 23 & 47 & 53 \\
\hline 9 & Litwa & 4 & 6 & 35 & 45 & 55 \\
\hline 10 & Francja & 7 & 18 & 18 & 44 & 56 \\
\hline 11 & Stowenia & 7 & 16 & 21 & 43 & 57 \\
\hline 12 & Irlandia & 3 & 14 & 26 & 43 & 57 \\
\hline 13 & Holandia & 5 & 14 & 23 & 43 & 57 \\
\hline 14 & Dania & 7 & 16 & 19 & 41 & 59 \\
\hline 15 & Szwecja & 7 & 19 & 15 & 41 & 59 \\
\hline 16 & Belgia & 11 & 7 & 21 & 39 & 61 \\
\hline 17 & Finlandia & 6 & 14 & 17 & 37 & 63 \\
\hline 18 & Włochy & 6 & 11 & 18 & 35 & 65 \\
\hline 19 & Austria & 5 & 11 & 17 & 34 & 66 \\
\hline 20 & Cypr & 4 & 17 & 13 & 34 & 66 \\
\hline 21 & Rumunia & 3 & 13 & 15 & 31 & 69 \\
\hline $\mathbf{2 2}$ & Polska & $\mathbf{3}$ & $\mathbf{1 0}$ & $\mathbf{1 6}$ & $\mathbf{3 0}$ & $\mathbf{7 0}$ \\
\hline 23 & Wielka Brytania & 6 & 5 & 13 & 24 & 76 \\
\hline 24 & Portugalia & 4 & 6 & 12 & 22 & 78 \\
\hline 25 & Estonia & 3 & 6 & 12 & 22 & 78 \\
\hline 26 & Czechy & 1 & 6 & 10 & 17 & 83 \\
\hline 27 & EU-27 & 6 & 11 & 17 & 34 & 66 \\
\hline & & & & & & 43 \\
\hline
\end{tabular}

Tabela 2. Udział sektora MSP w całkowitej wartości zamówień publicznych w krajach UE w latach 2006-2008 (w \%)

Źródło: opracowanie własne na podstawie M.P. Vincze, J. Mathis, A. Dumitrescu, A. Evbilgic, E. Coscia, M. Megliola, Evaluation of SMEs' Access to Public Procurement Markets in the EU, DG Enterprise and Industry, September 2010, s. 23. 


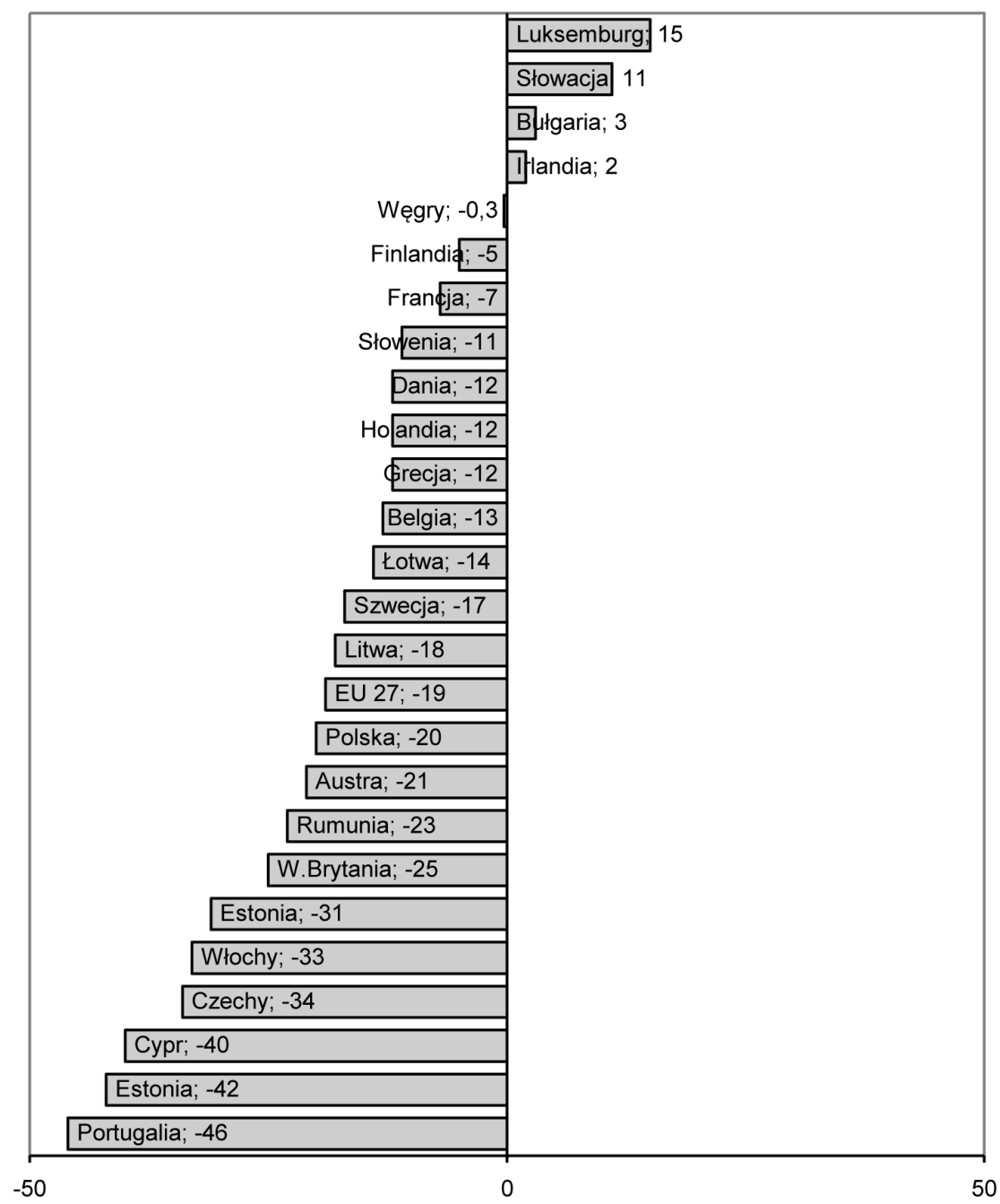

Wykres 1. Różnice pomiędzy udziałem MSP w realizacji zamówień publicznych oraz ich rolą w gospodarce* w krajach UE w latach 2006-2008

* Rolę sektora MSP w gospodarkach krajów członkowskich UE określono na podstawie udziałów podmiotów tego sektora w całkowitym obrocie gospodarczym. Źródło: M. P. Vincze et all., op. cit., s. 27.

$\mathrm{Na}$ podstawie powyższych wizualizacji można sformułować dwa wnioski. Pierwszy z nich konstatuje fakt, iż udział MSP w realizacji zamówień publicznych $\mathrm{w}$ drugiej połowie lat dwutysięcznych był w naszym kraju, na tle innych państw europejskich niski. Polska znalazła się bowiem w tym rankingu na 23 miejscu wśród 27 państw członkowskich Unii. Dodać jednak należy, iż Polska w zakresie omawianego wskaźnika była „gorsza” jedynie o 4 punkty procentowe od średniej unijnej. W za- 
kresie różnic pomiędzy udziałem w rynku zamówień publicznych oraz rolą w gospodarce sytuacja Polski była lepsza (wykres 1) - tym niemniej różnice pomiędzy przyjętymi wskaźnikami kształtowały się na poziomie 20 punktów procentowych, na niekorzyść udziału w rynku zamówień publicznych.

\section{Systemowe ułatwienia dostępu MSP do kontraktów publicznych w Polsce - stan obecny i przewidywane zmiany}

W toku ewolucji systemu zamówień publicznych polski ustawodawca prowadził dosyć konsekwentną politykę stosowania ułatwień dla sektora MSP w zakresie pozyskiwania kontraktów publicznych. Analizując rozwiązania wynikające $z$ aktualnie obowiązującej ustawy Pzp oraz te przewidziane do wprowadzenia $\mathrm{w}$ projekcie nowego Prawa zamówień publicznych wskazać można na trzy instrumenty mające ułatwić MSP dostęp do polskiego rynku zamówień publicznych. Są one następujące:
A) możliwość składania ofert wspólnych,
B) dopuszczalność zlecania części kontraktu podwykonawcom,
C) możliwość składania ofert częściowych. Dzielenie zamówienia na części.
Poniżej przedstawiamy charakterystykę tych rozwiązań.

\subsection{Możliwość składania ofert wspólnych (instrument A)}

Zarówno obecna ustawa Pzp, jak i projekt nowej ustawy, dopuszcza możliwość wspólnego ubiegania się o zamówienie publiczne.

Tabela 3 prezentuje zestawienie porównawcze podstaw prawnych oraz rozwiązań jakie z nich wynikają, zamieszczonych w obecnej ustawie Pzp oraz w projekcie nowego polskiego Prawa zamówień publicznych.

\begin{tabular}{|c|c|c|c|}
\hline \multicolumn{2}{|c|}{ Aktualna ustawa Pzp } & \multicolumn{2}{c|}{ Projekt ustawy Pzp } \\
\hline $\begin{array}{c}\text { Podstawa } \\
\text { prawna }\end{array}$ & \multicolumn{1}{|c|}{ Rozwiązanie systemowe } & $\begin{array}{c}\text { Podstawa } \\
\text { prawna }\end{array}$ & Rozwiązanie systemowe \\
\hline Art. 23 ust. 1 & $\begin{array}{l}\text { Możliwość wspólnego ubiegania } \\
\text { się o zamówienie }\end{array}$ & Art. 96 ust. 1 & $\begin{array}{l}\text { Możliwość wspólnego ubiega- } \\
\text { nia się o udzielenie zamówie- } \\
\text { nia („konsorcjum”) }\end{array}$ \\
\hline
\end{tabular}




\begin{tabular}{|c|c|c|c|}
\hline \multicolumn{2}{|r|}{ Aktualna ustawa Pzp } & \multicolumn{2}{|r|}{ Projekt ustawy Pzp } \\
\hline $\begin{array}{l}\text { Podstawa } \\
\text { prawna }\end{array}$ & Rozwiązanie systemowe & $\begin{array}{l}\text { Podstawa } \\
\text { prawna }\end{array}$ & Rozwiązanie systemowe \\
\hline Art. 23 ust. 2 & $\begin{array}{l}\text { Obowiązek ustanowienia } \\
\text { pełnomocnika przez wykonaw- } \\
\text { ców wspólnie ubiegających się } \\
\text { o zamówienie }\end{array}$ & Art. 96 ust. 2 & $\begin{array}{l}\text { Konieczność ustanowienia } \\
\text { przez konsorcjum pełnomoc- } \\
\text { nika }\end{array}$ \\
\hline \multirow[t]{3}{*}{$\begin{array}{l}\text { Art. } 96 . \\
\text { ust. } 3\end{array}$} & \multirow{3}{*}{$\begin{array}{l}\text { Prawo zamawiającego żądania } \\
\text { umowy regulującej współpracę } \\
\text { wykonawców którzy wspólnie } \\
\text { złożyli ofertę }\end{array}$} & Art. 96 ust. 3 & $\begin{array}{l}\text { Prawo zamawiającego żądania } \\
\text { umowy konsorcjum }\end{array}$ \\
\hline & & Art. 96 ust. 4 & $\begin{array}{l}\text { Zakaz narzucania konsorcjan- } \\
\text { tom przez zamawiającego } \\
\text { formy prawnej }\end{array}$ \\
\hline & & $\begin{array}{l}\text { Art. } 96 \\
\text { ust. } 5 \text { i } 6\end{array}$ & $\begin{array}{l}\text { Możliwość szczególnego } \\
\text { określenia warunków pod- } \\
\text { miotowych dedykowanych } \\
\text { konsorcjum }\end{array}$ \\
\hline \multirow[t]{2}{*}{ Art. 141} & \multirow[t]{2}{*}{$\begin{array}{l}\text { Solidarna odpowiedzialność } \\
\text { wykonawców wspólnie składają- } \\
\text { cych ofertę za wykonanie umowy } \\
\text { i wniesienie zabezpieczenia }\end{array}$} & Art. 96 ust. 7 & $\begin{array}{l}\text { Prawo zamawiającego żądania } \\
\text { określonej formy prawnej od } \\
\text { konsorcjum któremu udziela } \\
\text { zamówienie }\end{array}$ \\
\hline & & Art. 96 ust. 8 & $\begin{array}{l}\text { Nakaz odpowiedniego } \\
\text { stosowania do konsorcjów } \\
\text { przepisów dotyczących wyko- } \\
\text { nawców }\end{array}$ \\
\hline
\end{tabular}

Tabela 3. Zestawienie podstaw prawnych oraz rozwiązań jakie z nich wynikają w odniesieniu do ,instrumentu A"

Źródło: opracowanie własne na podstawie aktualnej ustawy Pzp oraz projektu nowego Prawa zamówień publicznych z 17.04.2015 r.

Jak widać, autorzy projektu nowego Prawa zamówień publicznych, w ślad za zmienioną dyrektywą UE, w sposób bardziej szczegółowy doprecyzowali instytucję konsorcjum. Fakt ten należy ocenić pozytywnie. Wynika bowiem z niego mniejsze ryzyko stosowania omawianego rozwiązania. Na szczególnie pozytywną ocenę zasługuje możliwość uwzględnienia przez zamawiającego specyfiki konsorcjów w odniesieniu do stawianych w danym postępowaniu warunków podmiotowych.

Na tle tej, ogólnie pozytywnej, oceny wątpliwości budzić musi jednak fakt nieumieszczenia w projekcie nowej ustawy przepisu ekwiwalentnego wobec art. 141 ustawy obecnie obowiązującej.

Pomimo oczywistego ułatwienia (adresowanego do MSP), jakim jest możliwość wspólnego składania ofert, oferty konsorcjalne na polskim rynku zamówień publicznych nie cieszyły się dotąd zbyt dużą popularnością. Tabela 4 przedstawia odsetek postępowań w których, w latach 2010-2015 (I-VI), przetargi były wygrywane przez konsorcja. 


\begin{tabular}{|l|c|c|c|}
\hline \multirow{2}{*}{ Rok } & \multicolumn{3}{|c|}{ Odsetek konsorcjów uzyskujących zamówienia na: } \\
\cline { 2 - 4 } & dostawy & usługi & roboty budowlane \\
\cline { 2 - 4 } & $100 \%=$ wszystkie postępowania rozstrzygnięte w danym roku \\
\hline 2010 & 0,34 & 2,67 & 5,60 \\
\hline 2011 & 0,36 & 2,06 & 4,67 \\
\hline 2012 & 1,78 & 2,84 & 3,91 \\
\hline 2013 & 2,53 & 2,81 & 3,45 \\
\hline 2014 & 3,04 & 3,26 & 4,32 \\
\hline 2015 (I-18.VI) & 3,74 & 3,83 & 5,15 \\
\hline Ogółem - odsetek & 1,76 & 2,95 & 4,46 \\
\hline Liczba obserwacji & 761264 & 559122 & 289799 \\
\hline
\end{tabular}

Tabela 4. Udział wygrywających przetargi stanowiących konsorcja w latach 2010-2015 (I-VI)

Źródło: obliczenia własne na podstawie ogłoszeń publikowanych w Biuletynie Zamówień Publicznych.

Jak wynika z tabeli, konsorcja najczęściej wygrywały przetargi na roboty budowlane. Jednakże nawet na tym rynku ich udział wśród „zwycięzców przetargów" - nie przekroczył poziomu 6\%.

\subsection{Dopuszczalność zlecenia części kontraktu podwykonawcom (instrument B)}

W obecnym stanie prawnym ustawa Prawo zamówień publicznych zawiera dość liberalne rozwiązania dotyczące możliwości powierzenia realizacji części zamówienia podwykonawcom. Jedynym prawem zamawiającego dotyczącym możliwości ingerencji w zakres wykonywanego przez podwykonawców zamówienia jest możliwość zobowiązania wykonawcy do osobistego wykonania kluczowych części zamówienia na roboty budowlane i usługi lub prac związanych $\mathrm{z}$ rozmieszczeniem i instalacją przedmiotu zamówienia w przypadku zamówień na dostawy. Powyższe zastrzeżenie jest jednak nieskuteczne $\mathrm{w}$ zakresie $\mathrm{w}$ jakim wykonawca powołuje się na zasoby innego podmiotu na podstawie art. 26 ust. 2 b ustawy w celu wykazania spełnienia warunków udziału $\mathrm{w}$ danym postępowaniu.

Ustawa daje jednak zamawiającemu odpowiednie narzędzia umożliwiające odpowiednią kontrolę nad procesem realizacji zamówienia przez podwykonawców. Zamawiający może żądać od wykonawców wskazania w ofercie zakresu zadań, które wykonane zostaną przez podwykonawców, a w przypadku powoływania się przez wykonawcę na zasoby podmiotów zewnętrznych przy wykazaniu spełnienia warunków udziału w postępowaniu również wskazania nazw (firm) podmiotów, które zostaną podwykonawcami. 
W procedowanym projekcie nowej ustawy Prawo zamówień publicznych nie zmieniły się kwestie zasadnicze dotyczące podwykonawstwa. Projekt nowej ustawy zawiera jednak uszczegółowiony zakres ochrony oraz praw i obowiązków poszczególnych stron w przypadku sporów co do zasadności wzajemnych roszczeń dotyczących realizacji zamówienia jako podwykonawca.

Podsumowując, należy stwierdzić, iż omawiany instrument ułatwienia dostępu MSP do rynku zamówień publicznych jest w stanie oddziaływać pozytywnie na dwa sposoby a mianowicie:

a) umożliwiając małym firmom, poprzez angażowanie podwykonawców, podejmowanie się realizacji dużych kontraktów (wariant rzadziej spotykany w praktyce) lub

b) umożliwiając małym firmom pośredni dostęp do rynku zamówień publicznych w charakterze podwykonawców (wariant występujący powszechnie).

W warunkach polskich opisane powyżej rozwiązania modelowe, w tym zwłaszcza wariant „b”, napotkały na istotne problemy praktyczne. Ich źródłem było wystąpienie zjawiska zatorów płatniczych w rozliczeniach dokonywanych pomiędzy generalnymi wykonawcami oraz podwykonawcami. Zjawisko to było szczególnie rozpowszechnione na rynku budowlanym, prowadząc do bankructwa wielu firm, w szczególności małych i średnich.

W tabeli 5 przedstawiamy, w charakterze syntetycznego podsumowania, podstawy prawne oraz rozwiązania szczegółowe dotyczące omawianego instrumentu w obecnej i projektowanej ustawie Pzp.

\begin{tabular}{|l|l|l|l|}
\hline \multicolumn{2}{|c|}{ Aktualna ustawa Pzp } & \multicolumn{2}{c|}{ Projekt ustawy Pzp } \\
\hline $\begin{array}{l}\text { Podstawa } \\
\text { prawna }\end{array}$ & \multicolumn{1}{|c|}{ Rozwiązanie systemowe } & $\begin{array}{l}\text { Podstawa } \\
\text { prawna }\end{array}$ & \multicolumn{1}{c|}{ Rozwiązanie systemowe } \\
\hline $\begin{array}{l}\text { Art. 2 } \\
\text { ust. 9b }\end{array}$ & $\begin{array}{l}\text { Legalna definicja umowy o pod- } \\
\text { wykonawstwo }\end{array}$ & $\begin{array}{l}\text { Art. 12 pkt. } \\
32\end{array}$ & $\begin{array}{l}\text { Legalna definicja umowy o pod- } \\
\text { wykonawstwo }\end{array}$ \\
\cline { 3 - 4 } & $\begin{array}{l}\text { Dział V, } \\
\text { rozdz. } \\
2 \text { (art. } \\
214-223)\end{array}$ & $\begin{array}{l}\text { Wyodrębnienie samodzielnego } \\
\text { rozdziału grupującego przepisy } \\
\text { dotyczące podwykonawstwa }\end{array}$ \\
\hline $\begin{array}{l}\text { Art. 36a } \\
\text { ust. 2 }\end{array}$ & $\begin{array}{l}\text { Prawo zamawiającego do zastrze- } \\
\text { żenia wykonania przez wykonaw- } \\
\text { cę określonych części zamówienia }\end{array}$ & Art. 214 & $\begin{array}{l}\text { Dopuszczalność powierzania } \\
\text { wykonania części zamówienia } \\
\text { podwykonawcy }\end{array}$ \\
\hline $\begin{array}{l}\text { Art. 36b } \\
\text { ust. 1 }\end{array}$ & $\begin{array}{l}\text { Prawo zamawiającego do wska- } \\
\text { zania przez wykonawcę części } \\
\text { zamówienia, które zamierza on } \\
\text { powierzyć podwykonawcom }\end{array}$ & Art. 215 & $\begin{array}{l}\text { Prawo zamawiającego do wska- } \\
\text { zania przez wykonawcę części } \\
\text { zamówienia, które zamierza on } \\
\text { powierzyć podwykonawcom }\end{array}$ \\
\hline
\end{tabular}




\begin{tabular}{|c|c|c|c|}
\hline \multicolumn{2}{|r|}{ Aktualna ustawa Pzp } & \multicolumn{2}{|r|}{ Projekt ustawy Pzp } \\
\hline $\begin{array}{c}\text { Podstawa } \\
\text { prawna }\end{array}$ & Rozwiązanie systemowe & $\begin{array}{c}\text { Podstawa } \\
\text { prawna }\end{array}$ & Rozwiązanie systemowe \\
\hline $\begin{array}{l}\text { Art. } 36 b \\
\text { ust. } 2\end{array}$ & $\begin{array}{l}\text { Warunkowa dopuszczalność } \\
\text { zamiany podwykonawcy }\end{array}$ & $\begin{array}{l}\text { Art. } 216 \\
\text { ust. } 4\end{array}$ & $\begin{array}{l}\text { W przypadku stwierdzenia przez } \\
\text { zamawiającego, że wobec da- } \\
\text { nego pod wykonawcy zachodzą } \\
\text { podstawy wykluczenia - zobo- } \\
\text { wiązanie wykonawcy do zastą- } \\
\text { pienia go innym podmiotem }\end{array}$ \\
\hline \multirow[t]{4}{*}{$\begin{array}{l}\text { Art. } 143 a \\
\text { ust. } 1\end{array}$} & \multirow{4}{*}{$\begin{array}{l}\text { Dotyczy: zamówień na roboty } \\
\text { budowlane o terminie wykonania } \\
\text { dłuższym niż } 12 \text { miesięcy. } \\
\text { Rozwiązania gwarantujące } \\
\text { terminową zapłatę wymagalnego } \\
\text { wynagrodzenia podwykonawcom }\end{array}$} & $\begin{array}{l}\text { Art. } 217 \\
\text { ust. } 1\end{array}$ & $\begin{array}{l}\text { Dopuszczalność, za zgodą } \\
\text { zamawiającego, zmiany podwy- } \\
\text { konawców }\end{array}$ \\
\hline & & $\begin{array}{l}\text { Art. } 217 \\
\text { ust. } 2\end{array}$ & $\begin{array}{l}\text { Warunki zmiany podwykonawcy, } \\
\text { na którego zdolności polegat } \\
\text { wykonawca w celu spełnienia } \\
\text { kryteriów kwalifikacji }\end{array}$ \\
\hline & & Art. 218 & $\begin{array}{l}\text { Odpowiedzialność generalnego } \\
\text { wykonawcy za prawidłową reali- } \\
\text { zację zamówienia }\end{array}$ \\
\hline & & $\begin{array}{l}\text { Art. } 220 \\
\text { ust. } 1\end{array}$ & $\begin{array}{l}\text { Jak w art. 143a, ust. } 1 \text { Pzp obo- } \\
\text { wiązującego obecnie }\end{array}$ \\
\hline $\begin{array}{l}\text { Art. } 143 b \\
\text { ust. } 2\end{array}$ & $\begin{array}{l}\text { Ustanowienie maksymalnego } \\
\text { terminu zapłaty wynagrodzenia } \\
\text { podwykonawcy*) }\end{array}$ & $\begin{array}{l}\text { Art. } 221 \\
\text { ust. } 2\end{array}$ & $\begin{array}{l}\text { Jak w art. 143b, ust. } 2 \text { Pzp obo- } \\
\text { wiązującego obecnie }\end{array}$ \\
\hline $\begin{array}{l}\text { Art. } 143 b \\
\text { ust. } 5,6,8\end{array}$ & $\begin{array}{l}\text { Zobowiązanie podmiotu zawiera- } \\
\text { jącego umowę z podwykonawcą) } \\
\text { do przedłożenia zamawiającemu } \\
\text { poświadczonej kopii tej umowy, } \\
\text { wobec której, w przypadku robót } \\
\text { budowlanych, zamawiający może } \\
\text { wnieść sprzeciw }\end{array}$ & $\begin{array}{l}\text { Art. } 221 \\
\text { ust. } 5,6,8\end{array}$ & $\begin{array}{l}\text { Jak w art. 143b, ust. 5, 6, } 8 \text { Pzp } \\
\text { obowiązującego obecnie }\end{array}$ \\
\hline $\begin{array}{l}\text { Art. } 143 c \\
\text { ust. } 1\end{array}$ & $\begin{array}{l}\text { Obowiązek zamawiającego } \\
\text { dokonania zapłaty wymagalnego } \\
\text { wynagrodzenia podwykonawcy } \\
\text { który zawarł zaakceptowaną przez } \\
\text { niego (roboty) lub przedłożoną } \\
\text { mu (dostawy, usługi) umowę } \\
\text { o podwykonawstwo }\end{array}$ & $\begin{array}{l}\text { Art. 222, } \\
\text { ust. } 1\end{array}$ & $\begin{array}{l}\text { Jak w art. 143c, ust. } 1 \text { Pzp obo- } \\
\text { wiązującego obecnie }\end{array}$ \\
\hline
\end{tabular}

Tabela 5. Zestawienie podstaw prawnych oraz rozwiązań jakie z nich wynikają w odniesieniu do ,instrumentu B"

* Dotyczy też dalszego podwykonawcy lub podwykonawców Źródło: opracowanie własne na podstawie aktualnej ustawy Pzp oraz projektu nowego Prawa zamówień publicznych z 17.04.2015 r. 
Dokonując szczegółowej analizy porównawczej przepisów odnoszących się do problematyki podwykonawstwa w obecnej ustawie Pzp oraz w jej projekcie, stwierdzić należy co następuje:

- w projekcie nowej ustawy Pzp problematykę podwykonawstwa dowartościowano poprzez poświęcenie jej odrębnej jednostki struktury formalnej tekstu, a mianowicie rozdziału $2 \mathrm{w}$ dziale V;

- autorzy projektu ustawy odebrali zamawiającemu prawo zastrzegania tych części zamówień, które wykonawca musi zrealizować osobiście. Z drugiej jednak strony zamawiający uzyskał prawo wykluczania podwykonawców $\mathrm{z}$ postępowania, o ile nie będą oni spełniali kryteriów kwalifikacji podmiotowej (art. 216 ust. 4);

- projekt ustawy Pzp wyraźnie stanowi, iż niezależnie od faktu zaangażowania podwykonawców to wykonawca odpowiada za prawidłowe wykonanie zamówienia.

\subsection{Możliwość składania ofert częściowych w postępowaniu o udzielenie zamówienia publicznego Dzielenie zamówienia na części - „Instrument C”}

\subsubsection{Wprowadzenie}

Obecny stan prawny, uniemożliwia dzielenie zamówienia publicznego na części w przypadku, gdyby prowadziło to do uniknięcia stosowania przepisów ustawy Prawo zamówień publicznych (art. 32 ust. 2). W każdym innym przypadku jest to zatem możliwe.

Obecna ustawa dopuszcza możliwość złożenia oferty częściowej, zdefiniowanej jako oferta, która zgodnie z treścią specyfikacji istotnych warunków zamówienia przewiduje wykonanie jedynie części zamówienia publicznego, z zastrzeżeniem opisanym powyżej. Zupełnie inne uregulowania omawianego instrumentu zawiera projekt nowej ustawy Prawo zamówień publicznych.

Rozwiązania, jakie w odniesieniu do omawianego instrumentu zastosowano w obecnej i w projektowanej ustawie - nie są do siebie w pełni „przystawalne”. Z tego powodu, inaczej niż w przypadku instrumentów poprzednich, omówimy je odrębnie.

\subsubsection{Rozwiązania aktualne - oferty częściowe}

Do kategorii ofert częściowych odnoszą się trzy przepisy aktualnej ustawy a mianowicie art. 2 pkt 6 (definicja legalna oferty częściowej), art. 36 ust. 2 pkt 1 (obowiązek zamawiającego opisania w SIWZ części zamówienia na które dopuszcza on się składanie ofert częściowych) oraz art. 83 ust. 2 (oferty częściowe dopuszczalne jedynie w przypadku zamówień podzielnych) i ust. 3 (określenie liczby ofert częściowych składanych przez jednego wykonawcę). 
Możliwość składania ofert częściowych, poza niektórymi rynkami ${ }^{13}$, nie cieszyła się wysoką popularnością. Tezę tę, na przykładzie zamówień związanych z inwestycjami budowlanymi, ilustruje tabela 6 .

\begin{tabular}{|c|l|c|}
\hline Lp. & \multicolumn{1}{|c|}{ Przedmiot zamówienia } & $\begin{array}{c}\text { Odsetek zamówień dopuszczają- } \\
\text { cych oferty częściowe }\end{array}$ \\
\hline 1 & Dokumentacja urbanistyczna & 11,65 \\
\hline 2 & Dokumentacja projektowa & 5,08 \\
\hline 3 & Zastępstwo inwestycyjne & 3,66 \\
\hline 4 & Nadzór inwestorski & 11,58 \\
\hline 5 & Wykonanie robót budowlanych & 7,03 \\
\hline 6 & Zaprojektowanie i wykonanie robót budowlanych & 5,46 \\
\hline
\end{tabular}

Tabela 6. Udział postępowań dopuszczających oferty częściowe w zamówieniach związanych z inwestycjami budowlanymi w latach 2010-2015(I kwartał)

$(100 \%$ = wszystkie zamówienia danego rodzaju) Źródło: obliczenia własne na podstawie o Biuletynu Zamówień Publicznych.

\subsubsection{Dzielenie zamówienia na części}

Do omawianego narzędzia popierania MSP na rynku zamówień publicznych odnoszą się dwa następujące przepisy projektowanej ustawy:

- art. 35 ust. 5, Przepis statuuje zakaz dzielenia zamówienia na części, jeśli podział taki skutkować miał nieobjęciem zamówienia odpowiednimi przepisami ustawy,

- art. 70. Przepis ten określa szczegółowe zasady związane z podziałem zamówienia publicznego na części. Kluczowa z tych zasad nakłada na zamawiającego obowiązek podania w protokole postępowania przyczyn dla których podziału zamówienia na części nie dokonał (ust. 5).

Jak wynika z powyższego syntetycznego zestawienia, projekt nowej ustawy Pzp nakłada de facto na zamawiających obowiązek dzielenia zamówienia na części mogące być przedmiotem ofert częściowych. Obowiązek ten stanowi spełnienie, wielokrotnie zgłaszanych zarówno w UE jak i Polsce, postulatów wprowadzenia takiego instrumentu jako szczególnie efektywnego rozwiązania ułatwiającego MSP dostęp do kontraktów publicznych.

13 Wiodącym przykładem są tu rynki zamówień na dostawy leków oraz sprzętu medycznego (drobnego i średniego) dla dużych szpitali. 


\section{Podsumowanie}

O faktycznej efektywności nowych rozwiązań promujących MSP na rynku zamówień publicznych zadecydują decyzje podejmowane $\mathrm{w}$ realnym życiu gospodarczym. Warunkiem koniecznym monitorowania tych rozwiązań jest natomiast rozszerzenie treści ogłoszeń o udzielonych zamówieniach publicznych o dane pozwalające zidentyfikować wielkość wykonawców, którym, w wyniku przeprowadzonych postępowań, przyznane zostały kontrakty publiczne.

\section{Bibliografia}

Europejski kodeks najlepszych praktyk ułatwiajacych dostęp MSI do zamówień publicznych, Komisja Wspólnot Europejskich, Dokument roboczy Służb Komisji, Bruksela 2008.

Komunikat Komisji Europejskiej z 3.03.2010 roku, Europa 2020, Strategia na rzecz inteligentnego i zrównoważonego rozwoju sprzyjającego włączeniu spotecznemu.

New developments in public procurement: 2009/2175(INI), Parlament Europejski Bruksela, Strasbourg 2009.

System zamówień publicznych w Polsce, red. Sadowy J., Warszawa 2013.
Vincze M.P., Mathis J., Dumitrescu A., Evbilgic A., Coscia E., Megliola M., Evaluation of SMEs' Access to Public Procurement Markets in the EU, DG Enterprise and Industry, September 2010.

Zielona Księga w sprawie modernizacji polityki UE w dziedzinie zamówień publicznych. W kierunku zwiększenia skuteczności europejskiego rynku zamówień, Komisja Europejska, Bruksela 2011.

Zielona Księga. Zamówienia publiczne w Unii Europejskiej - w poszukiwaniu rozwiq̨zań, Komisja Europejska, Bruksela 1998. 